\title{
DOES THE NEARCTIC KNOT (Calidris canutus islandica) APPEAR IN POLAND?
}

\author{
Włodzimierz Meissner and Jadwiga Gromadzka
}

\begin{abstract}
Meissner W., Gromadzka J. 2006. Does the Nearctic Knot (Calidris canutus islandica) appear in Poland? Ring 28, 2: 113-117.

The probability of the Nearctic Knot occurrence in Poland is discussed. Occasional appearing of this subspecies in Poland seems to be probable. The Nearctic Knot may be represented by individuals observed in Poland during winter and early spring or occurring during autumn migration and then recorded on wintering grounds in western Europe, and also by juveniles appearing not numerously in the first half of August, hence earlier than the probable period of arriving juveniles of the Siberian subspecies Calidris canutus canutus at the Baltic.
\end{abstract}

W. Meissner, Avian Ecophysiology Unit, Department of Vertebrate Ecology and Zoology, University of Gdańsk, Al. Legionów 9, PL-80-441 Gdańsk, Poland, E-mail: w.meissner@univ.gda.pl; J. Gromadzka, Ornithological Station, Museum and Institute of Polish Academy of Sciences, ul. Nadwiślańska 108, PL-80-680 Gdańsk, Poland; E-mail: jagagrom@stornit.gda.pl

Key words: Nearctic Knot, Baltic, ringing recoveries, biometrics

\section{INTRODUCTION}

The Knot (Calidris canutus) breeds in the high Arctic from the Taimyr Peninsula, through Chukotka, Alaska till north-eastern Canada and Greenland (Piersma and Davidson 1992). Six subspecies were recognized within its strongly fragmented breeding range. Two of them: C. c. canutus (called Siberian Knot) and C. c. islandica (called Nearctic Knot) appear in Europe (Tomkovich 1992, 2001). In Poland Knots have been occurring mainly during autumn migration along the seacoast (Tomiałojć and Stawarczyk 2003). In spring their records are rare, because migration from wintering towards breeding grounds is conducted by a few long-distance flights and there are no suitable stopover sites for this species along the Polish coast due to lack of regular tides. Tidal areas rich in benthic fauna are necessary for waders to complete migration by long-distance flights (Piersma and Davidson 1992, Meissner 2001). In the published sources on Polish avifauna only the Siberian Knot is mentioned (Tomiałojć 1972, 1990; Tomiałojć and Stawarczyk 2003), which breeds in central Siberia, mainly at the Taimyr Peninsula, and winters in western and south- 
ern Africa (Gromadzka 1985, Piersma and Davidson 1992). The Nearctic Knot nests in Greenland and in north-eastern Canada and has wintering grounds in tidal areas of western Europe (Piersma and Davidson 1992). The closest regular wintering site of the Nearctic Knot (about $500 \mathrm{~km}$ in straight line) is situated along western Danish coast (Piersma and Davidson 1992) and this subspecies appears at western Baltic sporadically (Frikke and Laursen 1992).

It was suggested earlier that Nearctic Knots may appear in Poland (Gromadzka 1992, Meissner 1992). In this paper all known facts and new data are summarized and critically evaluated.

\section{PHENOLOGY}

Adult Knots migrate along the Polish coast from mid-July to mid-September, whereas juveniles - from mid-August till the end of September (Gromadzka 1985, Meissner and Sikora 1995). Some juveniles however were observed earlier - at the beginning of August (Gromadzka 1992; Meissner 1992, 2005).

A few records of Knots observed in winter and early spring are known, e.g. single birds observed on 28 March 1977 in Słowiński National Park, on 15 January 1995 in Dziwnów, on 14 February 1998 near Chałupy and four birds seen on 28 March 1992 in the Biebrza Valley (Tomiałojć 1990, Tomiałojć and Stawarczyk 2003). The most probably these individuals belonged to $C$. $c$. islandica, which numerously winters along the North Sea costs, whereas C. c. canutus spends winter in Africa.

Juvenile Knots observed in the Gulf of Gdańsk in the first half of August also may be the Nearctic Knots, because so early arrival of juveniles from Central Siberia seems to be unlikely. Juvenile Knots start to depart from the Taimyr Peninsula not earlier than at the end of the first August decade (Tomkovich and Soloviev 1996), so at the same time (or even a little bit later) when the first Knots in juvenile plumage were observed along the Polish coast (Gromadzka 1992, Meissner 2005). The distance between the Taimyr Peninsula and southern Baltic coast is about 4000 $\mathrm{km}$. Similarly to other waders the juveniles in autumn migrate slower and stay longer at stopover sites than adults do (Gromadzka 1985, 1992). Juvenile waders in the Arctic start migration with very low fat reserves, which allow them only for short flights (Lindström 1998, Lindström et al. 2002). Thus, it seems that all records of juvenile birds in the first half of August may concern individuals of Nearctic subspecies, which finish the breeding season somewhat earlier than Siberian Knots (Glutz von Blotzheim et al. 1999) and have shorter distance to cover between breeding grounds in Greenland and southern Baltic.

\section{BIOMETRICS}

Nearctic Knots have on average shorter bill and longer wing than Siberian Knots (Cramp and Simmons 1986). Results of biometrical analysis (Meissner and Kamont 
2005) suggest that linear measurements of some adult Knots caught in autumn in the Gulf of Gdańsk region fit to the Nearctic subspecies (Fig. 1). Similar conclusion was reached by Nehls (1987) after a biometrical analysis of birds from the German Baltic coast. On the other hand, it should be borne in mind that biometrics cannot be decisive, due to the high degree of overlapping in linear measurements of both subspecies (Cramp and Simmons 1986). Moreover, juvenile Knots caught in southern Baltic showed inter-seasonal variation of measurements, especially in bill length (Meissner 2004). However, it remains unknown whether juveniles that are particularly small in their first autumn stay smaller for the rest of their lives.

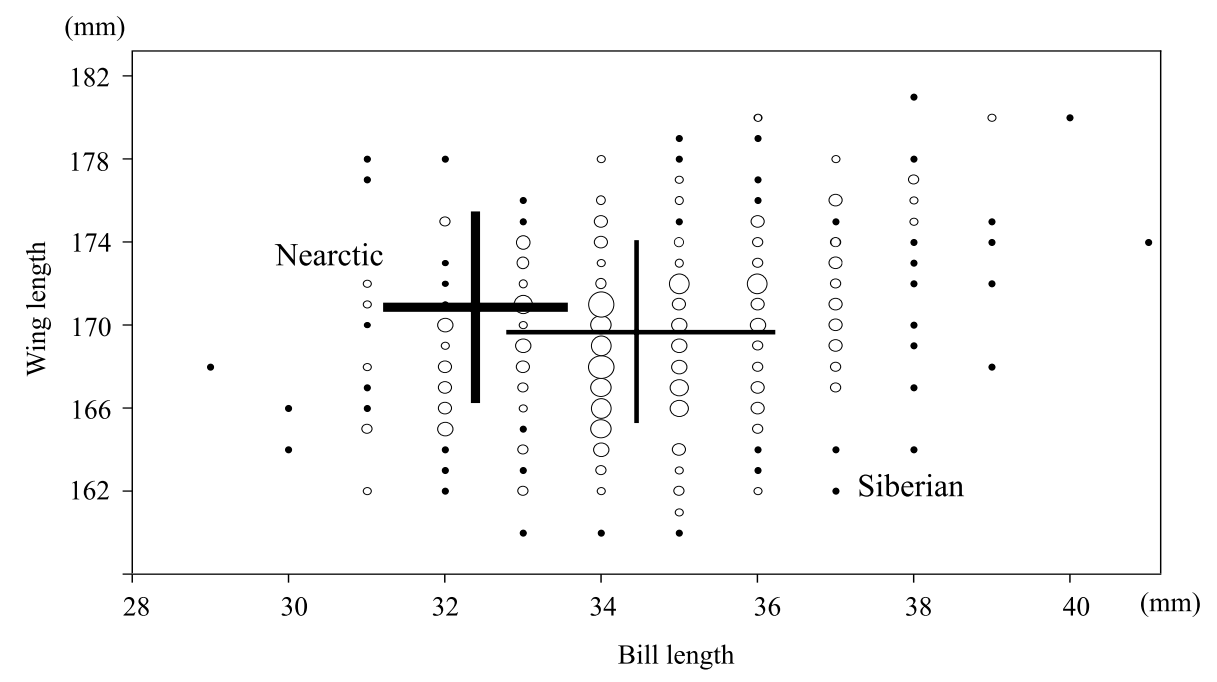

Fig. 1. Relationship between bill length and wing length of adult Knots caught in Puck Bay region (according to Meissner and Kamont 2005). Thick crossed lines indicate location of mean values $( \pm S D)$ for the Nearctic Knot, whereas thin crossed lines - for the Siberian Knot (according to Engelmoer and Roselaar 1998).

\section{RINGING RECOVERIES}

Till now in Poland there is no ringing recovery of a Knot ringed on the breeding grounds of the Nearctic subspecies. However, there are 17 recoveries from birds recorded in northern Poland during autumn migration (July-September) and in winter or early spring (between 20 December and 31 March) in Western Europe (Fig. 2) within the wintering range of the Nearctic subspecies. Fifteen of them (14 juveniles and 1 adult) concerned Knots ringed in Poland and recovered after some months (9 recoveries) or after few years (6 recoveries) in the Netherlands, Great Britain and France. The most interesting among them are two about adult birds ringed in February in England and recovered in Poland during autumn migration. Older birds may have gained knowledge about topographical features, staging areas, etc. and may thus be more likely to use wintering sites typical for the population. As 


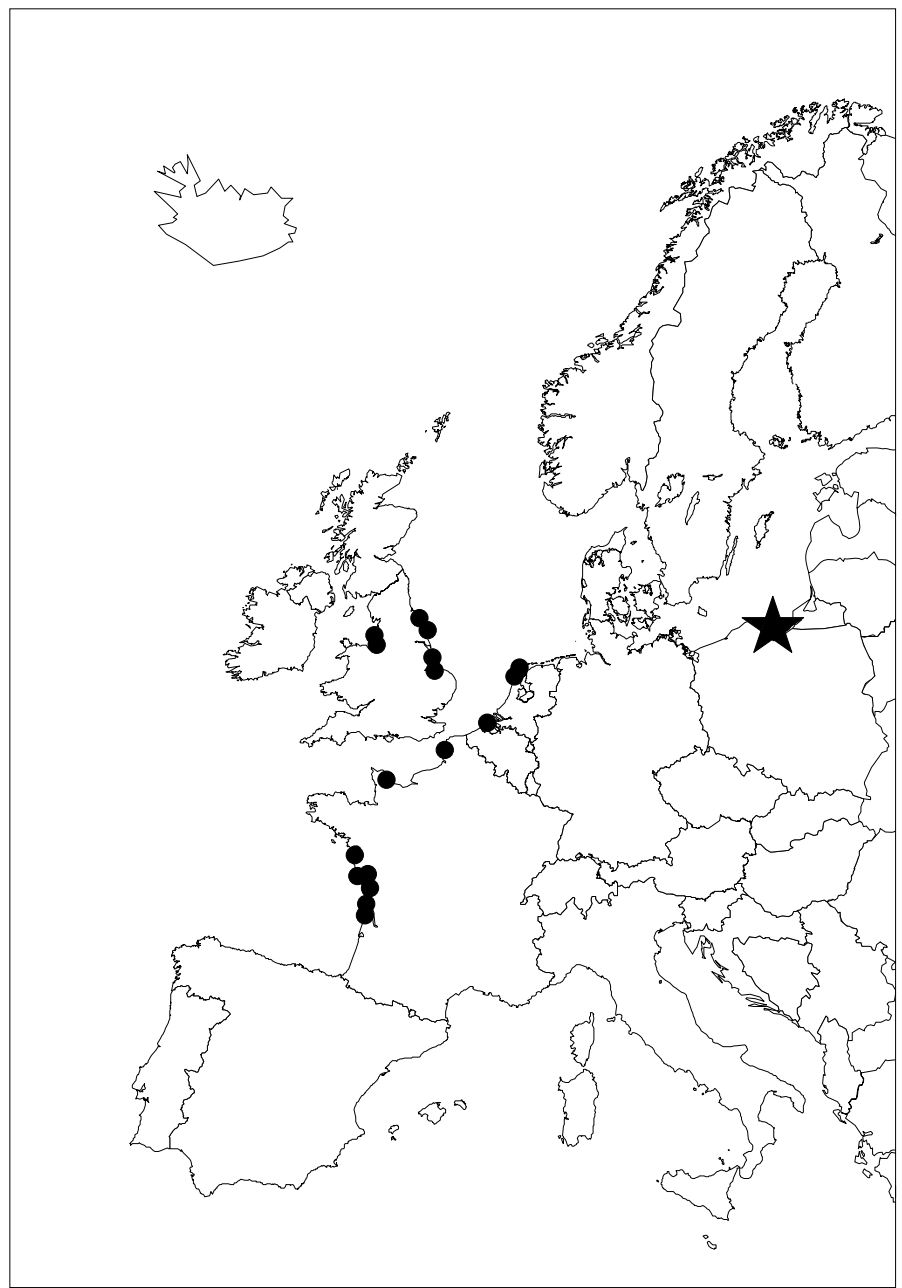

Fig. 2. Ringing recoveries of Knots ringed in autumn in northern Poland (asterisk) and recovered in winter (20 December - end of March) in western Europe or ringed on west European wintering grounds and caught in northern Poland in autumn

young birds are thought to migrate by an inherited vector navigation programme, they are expected to be displaced from migration route more often (Alerstam 1990). Nehls (1987) mentioned two more such recoveries about birds ringed at the German Baltic coast and recovered in winter in western Europe. However, it cannot be excluded that at least some Siberian Knots winter in Western Europe, despite the fact that the main wintering ground of this subspecies is situated in Africa (Glutz von Blotzheim et al. 1999).

Based on the recent knowledge of migration routes and biometrics of Knots (Piersma and Davidson 1992, Engelmoer and Roselaar 1998) it might be stated that 
among birds observed at the Polish coast the vast majority belong to the Siberian subspecies. Nevertheless, very early records of juvenile birds during autumn migration (the first half of August), biometrics of some birds and a few ringing recoveries suggest that the occurrence of the Nearctic subspecies in Poland is probable. Possibly also birds observed in Poland in winter end early spring belong to the islandica subspecies.

\section{REFERENCES}

Alerstam T. 1990. Bird migration. Cambridge Univ. Press, Cambridge.

Cramp S., Simmons K.E.L. (Eds). 1986. The Birds of the Western Palearctic. Handbook of the Birds of Europe, the Middle East and North Africa. vol. 3. Oxford Univ. Press, Oxford.

Engelmoer M., Roselaar C.C. 1998. Geographical Variation in Waders. Kluwer Academic Publishers, Dordrecht.

Frikke J., Laursen K.1992. Occurrence of the Knot Calidris canutus in Denmark, with special reference to the Danish Wadden Sea. Wader Study Group Bull. 64 (Suppl.): 155-160.

Glutz von Blotzheim U.N., Bauer K.M., Bezzel E. 1999. Handbuch der Vögel Mitteleuropas. vol. 6. AULA-Verlag, Wiesbaden.

Gromadzka J. 1985. Knot Calidris canutus. In: Viksne Y.A., Michelson Kh.A. (Eds). Migrations of birds of eastern Europe and northern Asia. Nauka, Moskwa.

Gromadzka J. 1992. Knots on the Polish Baltic coast. Wader Study Group Bull. 64 (Suppl.): 161-166.

Lindström Å. 1998. Mass and morphometrics of Little Stints Calidris minuta on autumn migration along the Arctic coast of Eurasia. Ibis 140: 171-174.

Lindström Å., Klaassen M., Piersma T., Holmgren N., Wennerberg L. 2002. Fuel stores of juvenile waders on autumn migration in high arctic Canada. Ardea 90: 93-101.

Meissner W. 1992. Knots' autumn migration in the western part of the Gulf of Gdansk, Poland: preliminary results. Wader Study Group Bull. 64 (Suppl.): 167-171.

Meissner W. 2001. Strategie wędrówkowe siewkowców (Charadrii) zachodniej Palearktyki. Wiad. Ekol. 47: 119-141.

Meissner W. 2004. Variability in the size of juvenile Red Knots Calidris canutus canutus. Wader Study Group Bull. 103: 71-74.

Meissner W. 2005. Variation in timing of the Siberian Knot Calidris c. canutus autumn migration in the Puck Bay region (southern Baltic). Acta orn. 40: 95-101.

Meissner W., Kamont P. 2005. Seasonal changes in body size and mass of Red Knots Calidris canutus during autumn migration through southern Baltic. Ornis Svecica 15: 97-104.

Meissner W., Sikora A. 1995. Spring and autumn migration of waders Charadrii on the Hel Peninsula. Not. Orn. 36: 205-237.

Nehls H.-W. 1987. Does the Nearctic Knot Calidris canutus islandica migrate through the south-western Baltic? Wader Study Group Bull. 51: 53-55.

Piersma T., Davidson N. 1992. The migrations and annual cycles of five subspecies of Knots in perspective. Wader Study Group Bull. 64 (Suppl.): 187-197.

Tomiałojć L. 1972. Ptaki Polski. Wykaz gatunków i rozmieszczenie. PWN, Warszawa.

Tomiałojć L. 1990. Ptaki Polski. Rozmieszczenie i liczebność. PWN, Warszawa.

Tomiałojć L., Stawarczyk T. 2003. Awifauna Polski. Rozmieszczenie, liczebność i zmiany. PTPP "pro Natura", Wrocław.

Tomkovich P.S. 1992. An analysis of the geographic variability in Knots Calidris canutus based on museum skins. Wader Study Group Bull. 64 (Suppl.): 17-23.

Tomkovich P.S. 2001. A new subspecies of Red Knot Calidris canutus from the New Siberian Islands. Bull. Br. Ornithol. Club 121: 257-263.

Tomkovich P.S., Soloviev M.Y. 1996. Distribution, migrations and biometrics of Knots Calidris canutus on Taimyr, Siberia. Ardea 84: 85-98. 